\title{
Forecasting domestic credit growth based on ARIMA model: Evidence from Vietnam and China
}

\author{
Doan Van Dinh ${ }^{a^{*}}$
}

${ }^{a}$ Faculty of Finance and Banking, Industrial University of Ho Chi Minh City, Ho Chi Minh, Vietnam

\begin{tabular}{l}
\hline C H R O N I C L E \\
\hline Article history: \\
Received: September 232019 \\
Received in revised format: Octo- \\
ber 292019 \\
Accepted: November 8, 2019 \\
Available online: \\
November 8, 2019 \\
\hline Keywords: \\
Autoregressive model \\
Autoregressive integrated moving \\
average \\
Credit Growth \\
Domestic credit \\
\hline
\end{tabular}

\section{A B S T R A C T}

\begin{abstract}
Credit is an economic category and is also a product of the commodity economy, which exists through many socio-economic forms to promote economic growth. Therefore, the objective of this paper is to analyst, compare and forecast domestic credit growth in Vietnam's and China's economy. Thus, the paper is applied by a method of an autoregressive integrated moving average (ARIMA) model. This model is fitted to time series data both to better understand the data and to forecast future points in the series. Hereby, the methodology is selected by Vietnam's best-fit model ARIMA $(2,3,1)$ and China's best-fit model ARIMA $(2,3,5)$. Analytical data are collected from 1996 to 2017, the sample fitted the model and is statistically significant. The result show the forecast result for next years. The Vietnamese and Chinese economy are the open economies and have domestic credit greatly contributed to economic growth. These results are the basis for policymakers to have a general view and define the impact of domestic credit growth on GDP between the two countries.
\end{abstract}

(C) 2020 by the authors; licensee Growing Science, Canada

\section{Introduction}

Autoregressive integrated moving average (ARIMA) Method is applied by many researchers to analyze and predict time series (Hodrick \& Prescott, 1997). This model was studied by George Box and Gwilym Jenkins in 1976. Based on time series, it can be explained by integration of past and present behaviors with random elements (white noise) in the present and the past. ARIMA model is an integration of two models: the autoregression model (AR) and Moving Average (MA) model. The research of data series using the ARIMA model must be stationary (lag). ARIMA model results in highly reliable short-term forecasts. Currently, the ARIMA forecast model has been widely used in many fields because of highly accurate forecast results. Therefore, previous studies used this method to analyze and forecast factors such as Inflation Rate, Long-Run Neutrality of Money in a Developing Country, GDP Series of Pakistan, and forecasting economic growth etc. The authors applied the Autoregressive Integrated Moving Average (ARIMA) model to forecast Zambia's inflation rate by using the monthly consumer price index (CPI) data from 2010 to 2014. The results showed that ARIMA $((12), 1,0)$ is a model best suited to time series data of CPI and forecast CPI and subsequently the inflation rate, (Jere \& Mubita, 2016; Kishwer et al., 2014). Other authors also applied ARIMA to forecast and analyze two variables: money supply and the log of real GDP (Seher Nur, 2011). To forecast the GDP, the author applied Autoregressive Integrated Moving Average models to construct following the Box-Jenkins technique. Hereby, the ARIMA $(1,1,0)$ model was chosen by considering the best fit model (MANIHA, 2014). These studies applied the ARIMA model to analyze and forecast economic topics. Thus, this article applies the ARIMA method to analyze and forecast the credit growth. It was known that the credit growth impacted on economic growth and is the transfer of saver's funds to the lenders (banks) to carry on business and production. That is the formation of money supply and demand relations between borrowers and lenders. This relationship is a necessity and is the factor play an important role in economic growth. More importantly, the credit supplies quantities capital through the commercial bank to the private sector and from capital redundant sector to capital lack sector. The literatures on growth suggest that the development of financial sector promotes economic growth. Usually, financial services work through efficient fund resource mobilization and credit expansion is to raise the level of investment and efficient capital accumulation (Seher Nur 2011; Sreerama et al., 2012). * Corresponding author.

E-mail address: citydinhninh@yahoo.com doanvandinh@iuh.edu.vn (D. Van Dinh) 
Moreover, the national savings and credit in the private sector play an important role in economic growth, an example of which is Pakistan (Muhammad et al., 2012). Therefore, it would seem that policies to develop credit in the financial sector would be expected to raise economic growth. However, if credit grows rapidly, there is a negative impact on economic growth. Credit is one of the factors that caused the global crisis, thus the relationship between credit and economic growth was investigated. The economy cannot grow without credit. This has determined the existence of a link between GDP and credit, the credit is provided to public investment, households and firms, etc. (Ioana, 2013).

The credit growth in Vietnam needs to be cautious to stabilize the macroeconomy and economic growth. Thus, the goal that the State Bank of Vietnam controls credit growth is in the match with economic growth. If banks fail to control credit growth well, this will lead to slow credit growth, causing the economy to be short of capital or fast credit growth, causing inflation to rise. According to economics, Keynesian and Friedman developed monetary transmission channels through exchange rates, share prices including credit channels (Mishkin, 2016). This is the channel that increases or decreases the monetary base. i.e., the credit growth (the quantity of commercial banks ' increased lend money) causes the increased quantity of money in circulation leading to the increased monetary base. This causes the economy inflation. Thus, the paper's objective is to analysis and forecast of the credit growth. This paper focuses on research on whether the credit growth has an impact on economic growth or not. If the credit growth is too fast, does it cause inflation? To assess the safety, financial stability of a country, the European Systemic Risk Board (ESRB) has developed a method: "credit gap ratio to GDP - Basel gap (\%)". This is a common method for measuring credit spreads to determine the difference between total credit to GDP and time series. The analyzed data is calculated by credit growth to GDP, i.e., this data has been compared between the credit growth and GDP and has shown different growth level between them. Therefore, the paper applies the ARIMA model to analyze the credit growth in the time series from 1996 to 2017 and forecast distinction between Vietnam's and China's credit growth to GDP with the trend in next years (Dinh, 2019). The paper applies the time series to analyze data of stationary time series, i.e., the article is used regression model to describe its behavior, which is used the appropriate model for forecasting purposes. It is known that the credit growth forecast is important for economic growth. Thus, the author applies the ARIMA model. Hereby, the autocorrelation model (AR (p)) that is a linear dependence of time-lag values and random errors, are applied. The Moving Average (MA (q)) that is the process described by its linear regression and time-lag values, is also applied, then the ARIMA Model (p, $\mathrm{d}, \mathrm{q}$ ) is integrated based on (AR (p)) model and MA (q)) model to determine the appropriate values of p, $d$ and $q$. The contribution of the article is measurement results through the method of statistical analysis with the time series from 1996 to 2017. The paper is used by the time series analysis and ARIMA methods to assess and forecast two countries' results of credit growth in the next years. This analysis shows that the level of credit growth is an important factor to assess the economic growth. The results also show that the credit growth is faster than GDP growth, causing inflation and bad debt of banks. The article structure is divided into 5 sections, the first section is the introduction, the second section is methodology and model, the third section is research results, the fourth section is the discussion, and the final section is the conclusion.

\section{Methodology and Data Analyses}

For most countries, the monetary base is used for the objective of stabilizing prices and promoting stable economic growth. Because the monetary base includes cash in circulation held by the non-banking public and reserves (including required reserves and excess reserves) of banking system that are opened their account in central banks. Therefore, the quantity of increased or decreased credit is relative to the government's loosened or tightened monetary policy. It is known that the increased credit makes increased money supply, thereby affecting inflation. The credit growth needs to be analyzed and assessed because the inadequacy credit growth causes not only inflation but also impacts on the economic growth. Hence, the authors applied the ARIMA model to analyze the credit growth. The literatures showed that the impact of credit on economic growth, unemployment and poverty was evidence from Indonesia. The authors studied the role of bank credit in promoting economic growth and reducing both unemployment and poverty. To analyze the link between bank credit and economic growth, the authors applied the Vector Autoregression (VAR) model and separated the variance of GDP growth. The bank credit was the most important for economic growth, Mangasa et al. (2016), (Dinh, 2019). Other research examined the impact of commercial bank credit on the private sectors for economic growth in Nepal. This study applied the Johansen Co-Integration Approach and Error Correction Model and used time series data to analyze the impact of commercial bank credit growth. Experimental results showed that bank credit for the private sector had positive impact on economic growth in Nepal in the long run (Neelam, 2014). Moreover, the literature was also related to credit growth and economic growth. These studies showed the impact of credit growth on economic growth in each country studied by different authors (e.g. Fapetu \& Obalade, 2015; Yakubu \& Affoi, 2014; Suna, 2015; Dinh, 2018).

It is known that the Box-Jenkins (BJ) method or it is called ARIMA methodology applied by many studies and this article is also applied by ARIMA model. This model is to analyze the probability or random nature of economic time series. Therefore, the researchers also applied this method to analyze and forecast time series for many different economic sectors. The study also analyzed and forecasted data of monthly interest rates of term deposits of commercial banks in Nigeria during 2005-2015 by the ARIMA model to propose a suitable forecast model of a time series for interest rate's data. The major statistical tools used in this study were time series analysis using ARIMA and State Space Modelling approaches (Omekara et al., 2016). Other studies applied ARIMA to analyze and forecast unemployment and CPI, inflation, the exports of industrial goods from Punjab for the ensuing decade until 2020. The savings and credit to private sector impacted on economic growth, domestic 
Consumer Price Index(CPI), the rates of inflation etc. (Charline et al., 2016; Aham, 2012; Muhammad et al., 2012; Fuat, 2011; Gulshan \& Sanjeev, 2010; Muhammad et al., 2016). There are many models used in forecasting but each model has its own advantages and limitations. However, the ARIMA model is one of the most popular linear models in time series forecast and it has been widely applied to establish more accurate hybrid models. This model was also assessed as suitable for linear relations between current data and past data (Mehdi \& Mehdi, 2011). Therefore, studies applied the ARIMA to analyze and forecast their research results such as the forecast of GDP, Forecast of Economic Growth and Forecast of Brent crude oil price, Forecast of Naira/USD Exchange Rate in Nigeria, Jordanian's GDP Prediction, Romania and Forecasting Bank Credit growth rate (Ammara et al., 2017; Claudiu 2010; Thabani, 2018; Emmanuel, 2016; Tao, 2016; Dennis et al., 2014). The articles studied the applicability of the ARIMA model to predict the factors affecting economic growth as mentioned above in order to find the best model for predicting fluctuations of individuals factors such as exchange rates, GDP, credit growth, etc. (Dinh, 2019). It is known, ARIMA models provide another approach to time series forecasting. Exponential smoothing and ARIMA models are the two most widely used approaches to time series forecasting and exponential smoothing models are based on a description of the trend and seasonality in the data, ARIMA models aim to describe the autocorrelations in the data. Moreover, ARIMA models allow both autoregressive (AR) components as well as moving average (MA) components. The usefulness of modelling AR components as modelling the "change since last time" and MA components capture smoothed trends in the data. The (I) in ARIMA determines the level of differencing to use, which helps make the data stationary. ARIMA models are more flexible than other statistical models such as exponential smoothing or simple linear regression. Research results also showed that the ARIMA model gives the best forecast results among the studied models. The error in the model is not large, thus this paper is used the ARIMA model to forecast credit growth.

\subsection{Methodology}

Bank credit is known as transaction of assets between the Bank (credit institution) and the borrower (economic organizations and individuals), in which the Bank (credit institution) transfers assets to the borrower for a certain period of time according to agreement and the borrower is responsible for unconditional repayment of both principal and interest for bank (credit institution) when payment is due. As said above, to assess the safety and financial stability of a country, the European Systemic Risk Board (ESRB) has developed a method. It is calculated by the formula:

RATIO $_{\mathrm{t}}$ is Credit to GDP (nominal GDP) in a fiscal year and is applied by formula:

$$
\operatorname{RATIO}_{\mathrm{t}}(\% \mathrm{Cr})=\frac{\text { CREDIT }_{\mathrm{t}}}{\mathrm{GDP}_{\mathrm{t}}}
$$

The credit to GDP ratio at time $t$ between the aggregate credit to the non-financial private sector (credit), using the broadest credit aggregate, and nominal GDP $\left(\mathrm{GDP}_{t}\right)$ are calculated. However, the RATIO $\mathrm{t}$ is calculated by $(1)$, which is available in the world Bank's database. When the credit to GDP ratio is high, the stability of the financial system becomes more sensitive to interest rate fluctuation. If a firm has sensitive interest rate of liabilities greater than sensitive interest rate of its assets, he needs to consider his borrowed capital, because the increased interest rate will reduce the firm' profits and a decline in interest rate will raise the firm' profits. However, financial leverage depends on interest rates and fluctuation in interest rates, if high or fluctuated interest rates will affect the profitability of the business. It is known, basis Gap analyses: (rate-sensitive assets minus rate-sensitive liabilities) multiply $\Delta$ interest rate equal to $\Delta$ in banking or entity profits i.e. the profits of the bank and the individuals or lenders from their loan are shared from the profits of borrowers (Mishkin, 2016). Thus, almost interest rates affect the profitability of the business through the increased or fluctuated interest rates, therefore, enterprises need to consider between the rate of return and interest rate. In case the interest rate is greater than or equal to the rate of return, the enterprise does not borrow, it made enterprises' size reduced. This may cause GDP to be decreased; that is not expected by governments. Vice versa, with the low and stable interest rates, businesses use the loan to increase the size of the business leading to more goods and services (Dinh, 2019). This makes the economy grown and it is the government's expectation. The problems in research as follows:

How does the ratio of credit to GDP impact economic growth?

How is the model of the credit-to-GDP model applied to forecast the government's economic growth and inflation? From the empirical results, how does the difference between the ratio of credit to GDP of Vietnam and China?

To solve the problems, the paper applies the ARIMA model for analysis and forecast. It is known that there are four methods of economic forecast based on time series data: (1) single equation regression model, (2) simultaneous equation regression model, (3) autoregressive integrated moving average (ARIMA), and (4) vector autoregressive model (VAR). However, this paper applies ARIMA to forecast credit growth in a stationary time series. The hypothesis $\mathrm{Y}_{\mathrm{t}}$ is domestic credit/GDP ratio (it is called $\% \mathrm{Cr}$ ) th $\mathrm{t}$, the model is written as follows:

$$
\left(\mathrm{Y}_{(\% \mathrm{Cr}, \mathrm{t})}-\delta\right)=\alpha_{1}\left(\mathrm{Y}_{(\% \mathrm{Cr}, \mathrm{t}-1)}-\delta\right)+\mathrm{u}_{\mathrm{t}}
$$


where: $\delta$ is the mean value of $\mathrm{Y}$ and $\mathrm{u}_{\mathrm{t}}$ is an uncorrelated random error term, with a mean value of 0 and a constant variance $\delta^{2}$ (white noise) then that $Y_{(\% \mathrm{Cr}, \mathrm{t})}$ follows the 1-degree autoregression or AR (1). This model indicates the predicted value of $\mathrm{Y}$ in period $\mathrm{t}$, that is the $\alpha_{1}$ value in the period $(\mathrm{t}-1)$ plus the random white noise factor during the time $(\mathrm{t})$ and the values of Y. If the autoregressive model of degree 2 or AR (2) is abided by this model and it is written as follows:

$$
\left(\mathrm{Y}_{(\% \mathrm{Cr}, \mathrm{t})}-\delta\right)=\alpha_{1}\left(\mathrm{Y}_{(\% \mathrm{Cr}, \mathrm{t}-1)}-\delta\right)+\alpha_{2}\left(\mathrm{Y}_{(\% \mathrm{Cr}, \mathrm{t}-2)}-\delta\right)+\mathrm{u}_{\mathrm{t}}
$$

The AR (1) and AR (2) are integrated and the general autoregressive model is written as follows:

$$
\left(\mathrm{Y}_{(\% \mathrm{Cr}, \mathrm{t})}-\delta\right)=\alpha_{1}\left(\mathrm{Y}_{(\% \mathrm{Cr}, \mathrm{t}-1)}-\delta\right)+\alpha_{2}\left(\mathrm{Y}_{(\% \mathrm{Cr}, \mathrm{t}-2)}-\delta\right)+\mathrm{u}_{\mathrm{t}}+\cdots+\alpha_{\mathrm{p}}\left(\mathrm{Y}_{(\% \mathrm{Cr}, \mathrm{t}-\mathrm{p})}-\delta\right)+\mathrm{u}_{\mathrm{t}}
$$

In this case, $Y_{(\% C r, t)}$ is (p) autoregression or AR (p). The AR (p) model has been set up, it is not the only model to predict, $\mathrm{Y}_{(\% \mathrm{Cr}, \mathrm{t})}$ but also the moving average model (MA) and the model is written as follows:

$$
\mathrm{Y}_{(\% \mathrm{Cr}, \mathrm{t})}=\mu+\beta_{0} \mathrm{u}_{\mathrm{t}}+\beta_{1} \mathrm{u}_{\mathrm{t}-1}
$$

where: $\mu$ is a constant and $\mathrm{u}$ is a pure random error term. Hereby, $\mathrm{Y}$ in time $(\mathrm{t})$ is a constant plus the moving average of the current and past errors. So, in this case, the $\mathrm{Y}$ is abided by the 1 degree moving average or MA (1). In case, the model is abided by the 2-degree moving average model, the MA (2) model is written as follows:

$$
\mathrm{Y}_{(\% \mathrm{Cr}, \mathrm{t})}=\mu+\beta_{0} \mathrm{u}_{\mathrm{t}}+\beta_{1} \mathrm{u}_{\mathrm{t}-1}+\beta_{2} \mathrm{u}_{\mathrm{t}-2}
$$

When the MA (1) and the MA (2) are integrated, this model becomes a general model MA (q):

$$
\mathrm{Y}_{(\% \mathrm{Cr}, \mathrm{t})}=\mu+\beta_{0} \mathrm{u}_{\mathrm{t}}+\beta_{1} \mathrm{u}_{\mathrm{t}-1}+\beta_{2} \mathrm{u}_{\mathrm{t}-2}+\cdots+\beta_{\mathrm{q}} \mathrm{u}_{\mathrm{t}-\mathrm{q}}
$$

The ARIMA model shows that $y$ has characteristics in both AR (p) and MA (q) models, so the $Y_{t}$ is abided by the ARIMA (1.1) model, i.e. the model is integrated by $\operatorname{AR}(p=1)$ and MA $(q=1)$, the model is written as follows:

$$
\mathrm{Y}_{(\% \mathrm{Cr}, \mathrm{t})}=\theta+\alpha_{1} \mathrm{Y}_{(\% \mathrm{Cr}, \mathrm{t}-1)}+\beta_{1} \mathrm{u}_{\mathrm{t}-1}+\beta_{0} \mathrm{u}_{\mathrm{t}}+\beta_{1} \mathrm{u}_{\mathrm{t}-1}
$$

The model is ARIMA $(1,1)$, where: $\theta$ is constant. Based on the above analytical problems, the ARIMA model is written in general, where $\mathrm{p}$ is the degree of autoregression and $\mathrm{q}$ is the degree moving average.

$$
\mathrm{Y}_{(\% \mathrm{Cr}, \mathrm{t})}=\alpha_{1}\left(\mathrm{Y}_{(\% \mathrm{Cr}, \mathrm{t}-1)}-\delta\right)+\cdots+\alpha_{\mathrm{p}}\left(\mathrm{Y}_{(\% \mathrm{Cr}, \mathrm{t}-\mathrm{p})}-\delta\right)+\mathrm{u}_{\mathrm{t}}+\mu+\beta_{0} \mathrm{u}_{\mathrm{t}}+\beta_{1} \mathrm{u}_{\mathrm{t}-1}+\cdots+\beta_{\mathrm{q}} \mathrm{u}_{\mathrm{t}-\mathrm{q}} ; \mathrm{RIMA}(\mathrm{p}, \mathrm{q}) .
$$

It is known, if a time series is the degree of 1 , its difference is zero, i.e. it has the stationary time series. Likewise, if a time series is the degree of 2 , its difference also is zero. So, if a time series is degrees of $d$, after calculating the difference of $d$, it has a difference of zero. Thus, if a time series (d) is computed to have the stationary time series and then applied for the ARIMA model (p, q). The initial time series is called ARIMA (p, d, q) that is a time series of moving average (MA) ( $q$ ) integrated autoregressions (AR) (p) in degrees of $\mathrm{p}$ of autoregressions and degrees of $\mathrm{d}$ of sequence times to calculate difference until it has a lag time series, and $q$ is the degrees of moving averages. The paper applies the ARIMA model for forecasting credit growth, so the question is made as follows: how is Yt identified to comply with AR (p) and MA (q) and the values of $\mathrm{p}, \mathrm{d}$ and $\mathrm{q}$ of ARIMA model? How much are values of $\mathrm{p}, \mathrm{d}, \mathrm{q}$ ? These questions are answered as follows: The first, this model is identified by the appropriate values of $\mathrm{p}, \mathrm{d}$ and $\mathrm{q}$ that are considered by the correlogram and the partial correlogram. The second, after it identifies the appropriate values of $\mathrm{p}$ and $\mathrm{q}$, the model is estimated by parameters of the autoregression and moving averages in the model. Otherwise, this calculation can be done by the least squares method or it must be estimated nonlinear parameter method. The third, the model had estimated the parameters of the autoregression and moving averages, then ARIMA model is selected specifically to estimate its parameters and consider whether it matches and is accepted by the data or not because another model may also be suitable for this data. Finally, ARIMA model is applied to forecast. In many economic fields, the predictions obtained from this method are more reliable than predictions from the other econometric models, especially for short-term forecasts. It is known, the main identification tools of the model are the autocorrelation function $(\mathrm{ACF})$, the partial autocorrelation function (PACF), and the correlation diagrams that are drawn based on these functions and their points and are drawn according to the latency. These issues are explained by the stationary time series data of credit growth. 


\subsection{Data analysis}

The dataset was collected from 1996 to 2017, not up to 2018, the actual domestic credit to GDP ratio is $154 \%$, because the paper's object is when there are the forecasted results of the domestic credit to GDP ratio of 2018, these results shall be compared with the actual domestic credit to GDP ratio of 2018 to see the accuracy of forecasted results and the compared results are tested in conclusion section. The domestic credit data source provided by the financial sector (\% of GDP) and collected from World Development Indicators (WDI) is a large database of development indices developed by the World Bank (WB).

Table 1

Domestic credit to GDP (\%)

\begin{tabular}{|c|c|c|c|c|c|}
\hline Year & Credit to GDP China & Credit to GDP Vietnam & Year & Credit to GDP China & Credit to GDP Vietnam \\
\hline 1996 & 92.49 & 20.12 & 2007 & 125.69 & 88.23 \\
\hline 1997 & 99.78 & 21.24 & 2008 & 118.74 & 86.86 \\
\hline 1998 & 112.06 & 21.97 & 2009 & 141.68 & 112.76 \\
\hline 1999 & 118.16 & 28.92 & 2010 & 142.20 & 124.66 \\
\hline 2000 & 118.40 & 35.15 & 2011 & 140.60 & 110.22 \\
\hline 2001 & 121.66 & 39.73 & 2012 & 149.08 & 104.91 \\
\hline 2002 & 141.82 & 44.78 & 2013 & 155.74 & 108.23 \\
\hline 2003 & 150.11 & 51.80 & 2014 & 167.24 & 113.77 \\
\hline 2004 & 138.67 & 61.93 & 2015 & 193.41 & 128.35 \\
\hline 2005 & 132.59 & 65.40 & 2016 & 215.18 & 140.06 \\
\hline 2006 & 131.58 & 69.18 & 2017 & 215.24 & 141.80 \\
\hline
\end{tabular}

The domestic credit of Table 1 provided by the financial sector includes all credits to various sectors on a gross basis, with the exception of credit to the central government, which is net. The financial sector includes monetary authorities and deposit money banks, as well as other financial corporations where data are available (including corporations that do not accept transferable deposits but do incur such liabilities as time and savings deposits). This shows that the collected data is highly reliable. Data from the above table is the basis for analysis and selection of the ARIMA model by statistical software method. Results are done by methodology. Hereby, the AR (p) and MA (q) models are computed by Sequence Plot, Autocorrelations (ACF-Box-Jenkins Method), Partial Autocorrelations (Partial-ACF) and then the matching forecast model is built based on the selected model.

\section{Result}

The ARIMA model $(p, d, q)$ is defined by $p, d$ and $q$ when the model has a 0 -degree difference $(d=0)$ then that the result as showed in figure 1 and 2 is to determine the lag of the model, but it is not the stationary. The results of research on the ARIMA model of China's non-stationary time series are as follows:

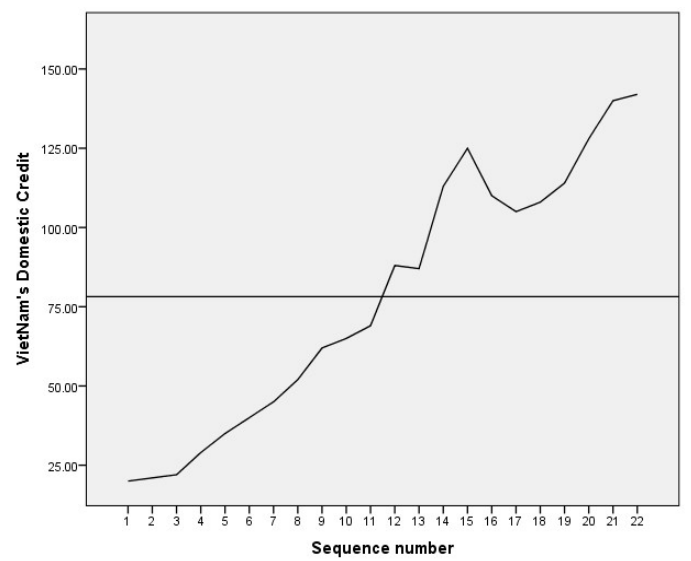

Fig. 1. Vietnam's Domestic Credit: difference $(d=0)$

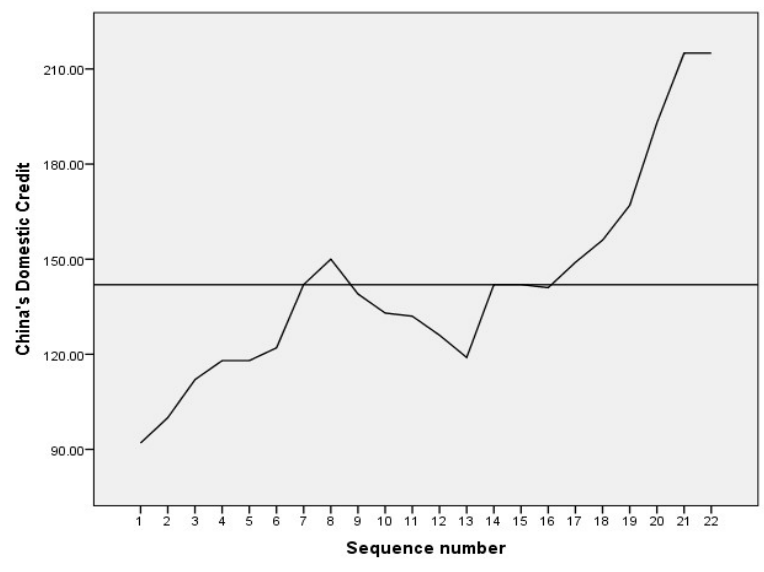

Fig. 2. China's Domestic Credit: difference $(\mathrm{d}=0)$

To consider the model's lag, they are made a 3-degree difference $(\mathrm{d}=3)$ then it has the result as in Fig. 3 and Fig. 4. The 3degree difference result $(\mathrm{d}=3)$ of China's time series has stationary like Vietnam's stationary time series. 


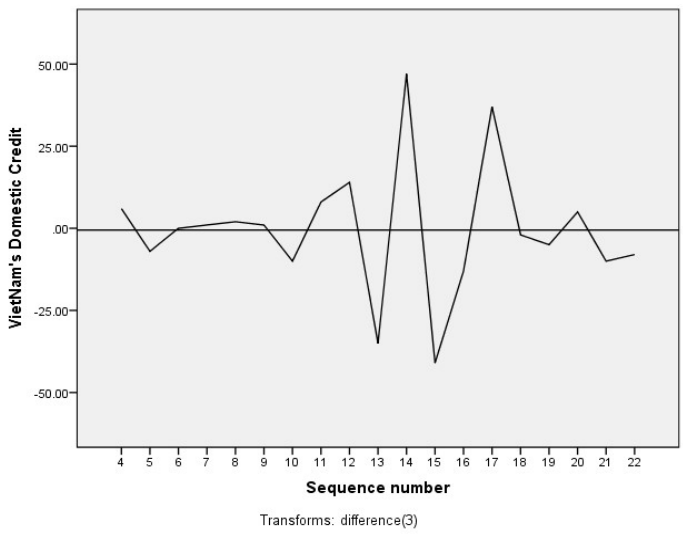

Fig. 3. Vietnam's Domestic Credit: difference $(d=3)$

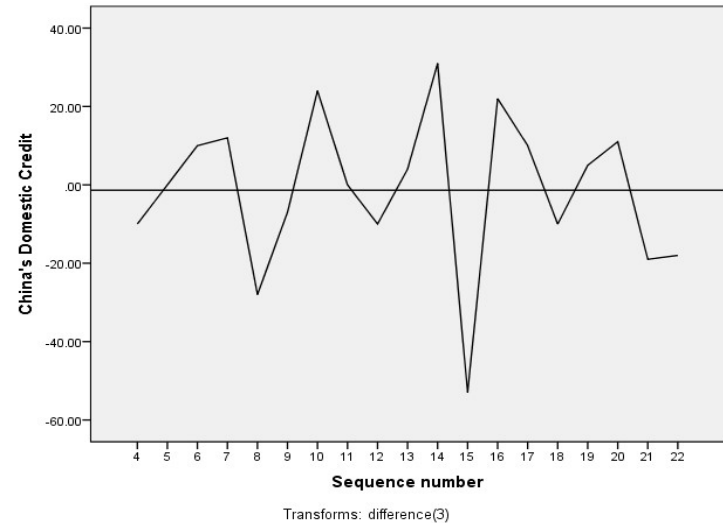

Fig. 4. China's Domestic Credit: difference $(\mathrm{d}=3)$

To determine $\mathrm{p}$ and $\mathrm{q}$, Box and Jenkins (1976) showed that the identification method was stationary of p and q autocorrelations if reduction of the correlation coefficients was in slowly or exponentially sinusoidal form. The individual correlation coefficients decreased dramatically down to 0 means immediately after the stationary of $p$ and $q$. The difference usually reduces the number of large autocorrelations considerably. If the differenced series still does not appear stationary, it would be had to differentiate again. It is often useful to determine the magnitude of a large autocorrelation and partial autocorrelation coefficient.

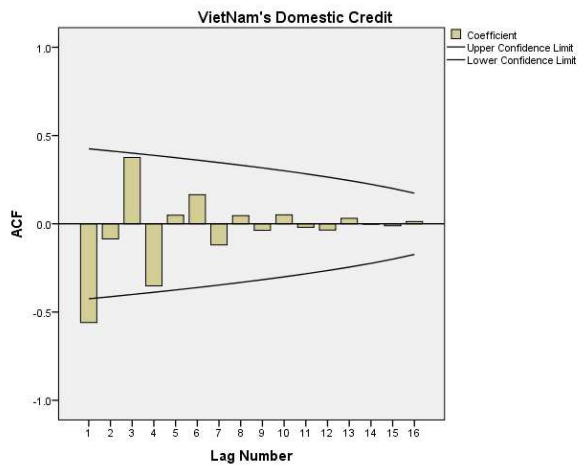

Fig. 5. Vietnam's Series Autocorrelation Plots (The Box Jenkins Method, (q=1)

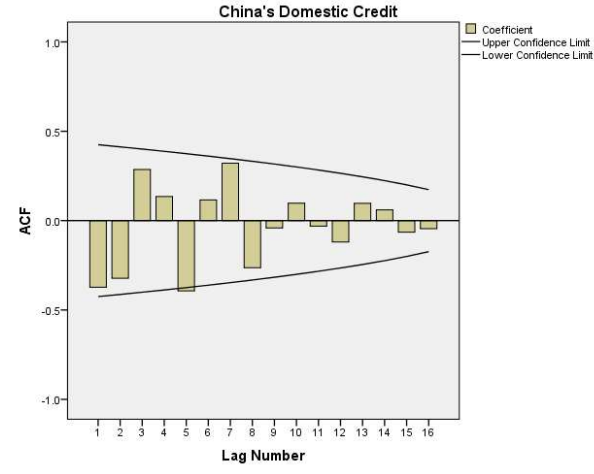

Fig. 6. China's Series Autocorrelation Plots (The Box Jenkins Method, $(\mathrm{q}=5))$

The empirical results show that the lag of the Chinese model differs from the lag of the Vietnamese model ( $q=5)$ and it is identified by the partial autocorrelation function (PACF). The forecast model is identified to comply with AR (p) and the main identification tools of the model are the autocorrelation function (ACF).

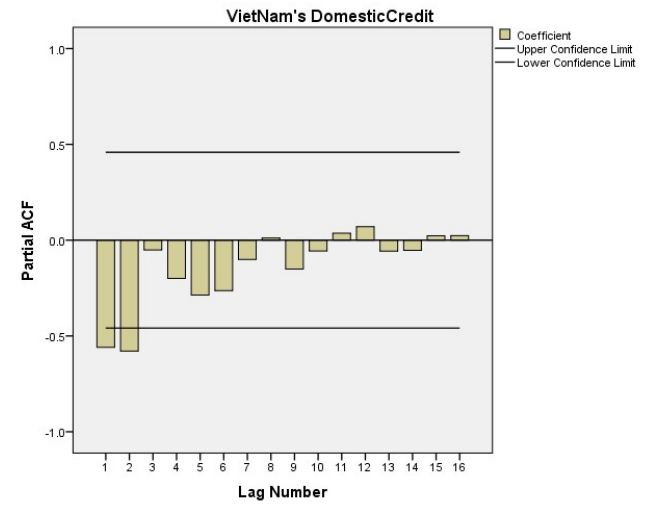

Fig. 7. Vietnam's Series Autocorrelation Plots (The Box Jenkins Method, $(\mathrm{p}=1$ \& 2))

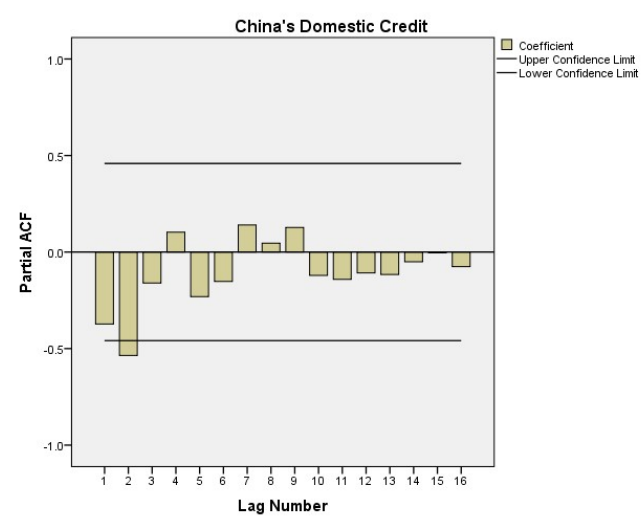

Fig. 8. China's Series Autocorrelation Plots (The Box Jenkins Method, $(\mathrm{p}=2))$ 
The results show that the lag of the Chinese model is lag $2(\mathrm{p}=2)$ and China's time series has a forecast model at lag 2, but. Vietnam's time series has two different forecast models at lag 1 and lag 2. However, Vietnam's model is selected lag 1 or lag 2 from these two lags. The autocorrelations seem to die down fairly regularly after the lag of $\mathrm{q}=1$, $\mathrm{d}=3$ and $\mathrm{p}=1$ \& 2 of Vietnam's model lead to have ARIMA $(2,3,1)$ model and ARIMA $(1,3,1)$. However, the results in table 3 show that the ARIMA Model $1(2,3,1)$ is more suitable than ARIMA Model $2(1,3,1)$ because the ARIMA Model $1(2,3,1)$ has high Stationary R-squared, low RMSE and Normalized BIC. Thus, this model is selected for analyze and forecast. Besides, the autocorrelations also seem to die down fairly regularly after the lag of $q=5, d=3$ and $p=2$ of China's ARIMA $(2,3,5)$ model. The partial autocorrelations seem to be small after the lag one and two, thus, this is decided to fit an ARIMA $(2,3,1)$ and ARIMA $(2,3,5)$ to these data. The results also show that the autocorrelations or the partial autocorrelations cut off, a mixed model is suggested to be forecast ARIMA $(2,3,1)$ and $(2,3,5)$ models.

Table 2

Compared between the model Statistics of domestic credit/GDP ratios Vietnam and China

\begin{tabular}{|c|c|c|c|}
\hline \multirow[t]{2}{*}{ Model } & \multicolumn{3}{|c|}{ Model Fit statistics } \\
\hline & Stationary R-squared & RMSE & Normalized BIC \\
\hline Vietnam's Domestic Credit-Model_1_ARIMA $(2,3,1)$ & 0.699 & 12.111 & 5.408 \\
\hline Vietnam's Domestic Credit-Model_2 ARIMA $(1,3,1)$ & 0.646 & 12.713 & 5.550 \\
\hline China's domestic Credit -Model_1 ARIMA $(2,3,5)$ & 0.739 & 12.993 & 6.369 \\
\hline
\end{tabular}

For each model, forecasts start after the last non-missing in the range of the requested estimation period and end at the last period for which non-missing values of all the predictors are available or at the end date of the requested forecast period, whichever is earlier.

Source: Author's analyses

The results in Table 2 are the basis for selecting the most fit model by comparing those indicators which are Stationary Rsquared, RMSE and Normalized BIC of two models. Vietnam's Domestic Credit-Model_1 _ ARIMA $(2,3,1)$ is selected because it has the smallest RMSE, BIC and biggest R-squared.

Table 3

Compared between the credit to GDP ratio forecasts of Vietnam and China

\begin{tabular}{|c|c|c|c|c|c|c|}
\hline Model & & 2018 & 2019 & 2020 & 2021 & 2022 \\
\hline \multirow{3}{*}{$\begin{array}{l}\text { DomesticCreditVietNam-Model_1 } \\
\text { ARIMA }(2,3,1)\end{array}$} & Forecast & 148.57 & 155.54 & 159.98 & 164.46 & 168.66 \\
\hline & UCL & 173.69 & 202.82 & 230.65 & 264.18 & 301.16 \\
\hline & LCL & 123.44 & 108.26 & 89.30 & 64.74 & 36.16 \\
\hline \multirow{3}{*}{$\begin{array}{l}\text { DomesticCreditChina-Model_1 ARIMA } \\
\qquad(2,3,5)\end{array}$} & Forecast & 232.55 & 264.83 & 289.50 & 318.99 & 363.98 \\
\hline & UCL & 256.77 & 307.00 & 345.58 & 390.30 & 450.64 \\
\hline & LCL & 208.32 & 222.67 & 233.42 & 247.68 & 277.32 \\
\hline $\begin{array}{l}\text { Forecast result difference between Vietnam } \\
\text { and China }\end{array}$ & & $\mathbf{- 8 8 . 9 8}$ & -109.29 & -129.52 & -154.53 & -195.32 \\
\hline
\end{tabular}

For each model, forecasts start after the last non-missing in the range of the requested estimation period, and end at the last period for which non-missing values of all the predictors are available or at the end date of the requested forecast period, whichever is earlier.

Source: Author's analyses.

The results in the above tables are to describe the forecasted data of credit growth over the years. Besides, these results are also described in Fig. 9 and Fig. 10 to indicate more general of Vietnam's and China's models.

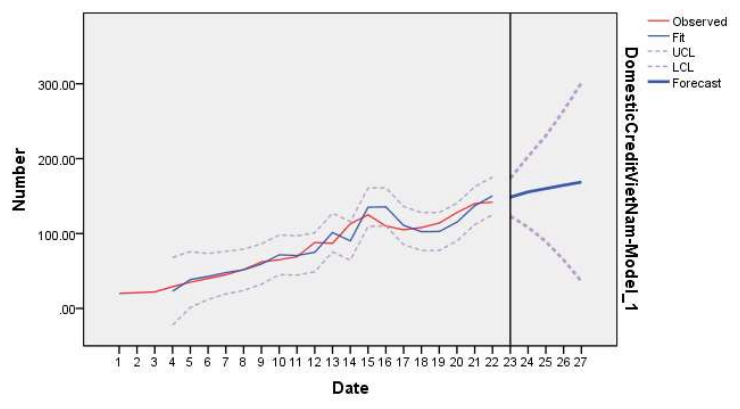

Fig. 9. Vietnam's forecast of Domestic Credit-Model

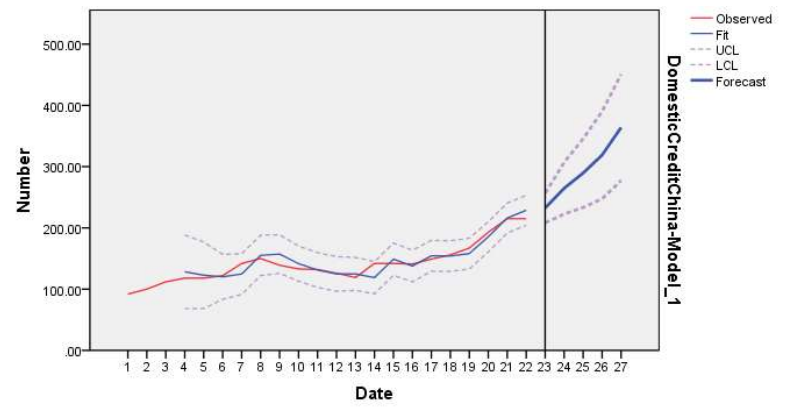

Fig. 10. China's forecast of Domestic Credit-Model

The forecast results of the Vietnamese model tend to go down, but the forecast results of the Chinese model tend to go up. This is the difference between the two models of the two economies, which is also the impact of two different monetary policies. These results are the basis for evaluating the analysis and making recommendations to the government for future economic development strategies. 


\section{Discussion}

It is known, high credit rates mean that the economy has more capital to do business. However, the credit to GDP ratio is high, the government should consider the efficiency of capital use because firms (entities) borrow more capital, they must pay more principal and interest. In this case, firms' credit-using also is their financial leverage using, but the optimal financial leverage ratio is limited. Because, if the leverage ratio exceeds this level, the gains will be less than the cost, i.e. the efficiency of capital use will decrease. This will reduce their demand for loans and it decreases GDP. It is known, the credit leads to an increase in spending, thus increasing income levels in the economy. This leads to higher GDP (gross domestic product) and thereby faster productivity growth. If credit is used to purchase productive resources, it helps in economic growth and adds to income. Thus, Vietnam's credit to GDP ratio is compared with China's the credit to GDP ratio as follows:

For Vietnam, in 2017, with the credit to GDP ratio of $141.797 \%$, it means that Vietnam's economy is borrowing 1.4 times more than its annual income. If the credit/GDP ratio continues to rise further, the pressure on debt repayment of enterprises may increase and the risk of default will be greater, this will make it and banks bankrupt because of bad debt. From these issues, the paper has applied the ARIMA model to analyze the time series of annual credit growth data. Fig. 1 shows that this fluctuation rate is unstable; especially large fluctuation was from 2008 to 2015. During this period, Vietnam's economy suffered inflation from 2008 to 2013 and Credit to GDP ratio fluctuated unexpectedly and it affected the growth of Vietnam's economy. After that, the economy developed steadily and the credit to GDP ratio grew steadily in 2014, 2015,2016 and 2017 , the credit / GDP ratio respectively increased by $113.767 \%, 128.347 \%, 140.062 \%$ and $141.797 \%$.

For China, China's credit to GDP ratio result shows that China's credit to GDP ratio is increased by $140.60 \%, 149.08 \%$, $155.74 \%, 167.24 \%, 193.41 \%, 215.18$ and $215.24 \%$ respectively from 2011 to 2017 . This result shows that China's credit to GDP ratio is higher than Vietnam's credit to GDP ratio. To increase the credit to GDP ratio, the Chinese government has carried out two important functions: ensuring price stability and promoting growth through monetary policies. China's central bank has lowered and stabilized interest rates, thereby, reducing borrowing costs and motivating businesses and individuals to borrow for investment and trading to grow the economy. This also shows that the Chinese government has set interest rates as the Federal Reserve System (Fed) and the European Central Bank (ECB). In addition, he has also built interest rate corridors with ceiling and floor limits to stabilize interest rates.

The comparison results above showed that the increase in credit ratios also means the debt ratio. According to vice-head of the Chinese Academy of Social Sciences Economic Research Institute, in 2018 the overall leverage ratio (debt-to-GDP ratio) of China's real economy was $243.7 \%$, with the household leverage ratio standing at $53.2 \%$, corporate leverage at $153.6 \%$ and government leverage at $37 \%$ (Speaking at $50^{\text {th }}$ China Economics Forum on 16 February, 2019). This is also consistent with the results of China's credit to GDP forecast in Table 3. According to the Vice Governor of the State Bank of Vietnam, the credit growth of Vietnam's central bank is more cautious to avoid bad debt. Therefore, the State Bank of Vietnam has a policy to strictly control credit. The credit growth orientation of central banks in 2019 shall remain at $14 \%$ (equivalent to credit to GDP: 158\%), which is also consistent with the forecasted results in Table 3), equivalent to $13.98 \%$ growth in 2018 (credit to GDP: $154 \%$ ). The results showed credit to GDP of $140.06 \%, 141.80 \%, 144 \%$ respectively in 2016,2017 and 2018 . This is the difference between Vietnam's credit policy and China's credit policy. The results in Table 3 indicated the average difference between China's credit-to-GDP ratio and Vietnam's credit-to-GDP ratio of 135,528\%. Although the comparative results of the ratio of credit to GDP of Vietnam are very low, the State Bank of Vietnam continues to maintain the stable monetary policy orientation as in the past years, that was the direction of controlling the credit to GDP ratio but it ensured capital for economic growth. Thus, forecast results are significance and relevance for making Vietnam's and China's monetary policies.

In order to analyze the volatility of the credit growth rate, the article applies the 3 -degree difference $(\mathrm{d}=3)$, the result is a time series of its fluctuation around a mean value as shown in figure 2 . The level of difference is estimated by considering the autocorrelation plots. When the autocorrelations die out quickly, the appropriate value of $d$ has been found. This is seen as the lag and is also base to identify the value of (p) and (q). The value of $p$ is determined from the partial autocorrelations of the appropriately differenced series. If the partial autocorrelations cut off after a few lags, the last lag with a large value would be the estimated value of $p$. If the partial autocorrelations do not cut off, its either have a moving average model ( $p=2)$ or an ARIMA model with positive $\mathrm{p}$ and $\mathrm{q}$. The value of $\mathrm{q}$ is found from the autocorrelations of the appropriately differenced series. If the autocorrelations cut off after a few lags, the last lag with a large value would be the estimated value of $q$. If the autocorrelations do not cut off, its either have an autoregressive model ( $q=1$ of Vietnam's model and q=5 of China's model) or an ARIMA model with a positive $\mathrm{p}$ and $\mathrm{q}$ (Box and Jenkins, (1976). Thus, the ARIMA model is selected to be Vietnam's ARIMA $(2,3,1)$ model and China's ARIMA $(2,3,5)$ model as estimated, these results are in the summary table of statistical results in Table 2, Table 3 and Figure 4. Empirical results in the forecast are matching with the reality as the result of the credit to GDP ratio and the forecasted average credit to GDP ratio. Moreover, this model also shows that the forecasted results in Table 3 are the upper and lower confidence limits (UCL, LCL). It is important results so that the government can refer to these results for controlling credit growth in the next years. 


\section{Conclusions}

In statistics, an autoregressive integrated moving average (ARIMA) model is integration of a moving average (MA) (q) and autoregressions (AR) (p). These models are fitted to time series data either in order to better understand the data or to predict future points in the series. The paper is based on this model to estimate the credit / GDP ratio of time series (1996-2017) and the results show the optimal forecast model with $p=2, q=4$ and $d=3$. Empirical results show that the forecasted data is reliable and the data is consistent and statistically significant. So, the article applies the ARIMA model to forecast credit / GDP ratio and find the best model for forecasting domestic credit growth of Vietnam economy. Research results show that the ARIMA $(2.3,1)$ model and the ARIMA $(2.3,5)$ model have the best predictive results as mentioned above. Planners should use this model to forecast credit growth to improve the feasibility of their macro plans. The research has found out Vietnam's forecasted results of domestic credit growth of $159.98 \%, 164.46 \%$ and $168.66 \%$ from 2020 to 2023. According to Governor of the State Bank of Vietnam (SBV) said that "credit growth of 14\% is suitable for the current context. The size of Vietnam's credit growth over GDP is over $141.80 \%$, which is the level that many foreign rating agencies have made recommendations. The direction of the Governor is to ensure the capital demand for the economy but still control the risk". In 2019, the Governor of the SBV has issued a target of $14 \%$ of the target of expected credit growth. This rate is IMF's recommendations for developing countries, the average annual credit should not increase by more than $14 \%$. This is actual results $(141.80 \%+14 \%=$ $155,80 \%$ in 2019) to compare it with the forecasted results of domestic credit/GDP ratios of $148.57 \%$ and $155.54 \%$ in 2018 and 2019 in this paper, that is absolutely correct. Therefore, these forecasted results are to forecast for the next years with high reliability. The above credit growth forecast shows that the State Bank should set the annual average credit growth target of $8.73 \%, 8.51 \%, 5.63 \%, 5.32 \%$ and $6.05 \%$ for years of 2020, 2021, 2022 and 2023 respectively. In which, the credit will still be focused on priority areas, ensuring risk control and supporting economic growth. The research has found out China's forecasted results of domestic credit growth of $289.50 \%, 318.99 \%$ and $363.98 \%$ from 2020 to 2023. This shows that China's credit growth rate is faster than Vietnam's credit growth. Forecasted results show that credit growth in 2021 is compared to credit growth in 2022 increased by 10\%, but credit growth in 2023 is compared to credit growth in 2022, increased by $14 \%$. Meanwhile, Vietnam's credit growth forecast is increased by $4.4 \%$. This shows that Vietnam's credit growth policy is more prudent than China's credit growth policy because Vietnam has tightened credit capital. This seems to reduce Vietnam's GDP growth. Therefore, the Vietnamese government should manage bad debt well and use borrowed capital effectively to loosen credit for economic growth.

\section{References}

Aham, K. U. (2012). Inflation forecasts with ARIMA, vector autoregressive and error correction models in Nigeria. European Journal of Economics, Finance and Administrative Sciences, 50, 71-87.

Ammara, N., Rabia, A., Sabahat, N., \& Noman, Q. (2017). Model building and forecasting of bank credit to public and private sector. Universal Journal of Accounting and Finance, 5(4), 73-77.

Box, G., \& Jenkins, G. (1976). Time Series Analysis. (R. Holden-Day, Ed.) San Francisco: John Wiley \& Sons, Inc.

Charline, U., Joseph, M., \& Jean, d. D. (2016). Forecasting inflation in Kenya using Arima - Garch Models. International Journal of Management and Commerce Innovations, 3(2), 15-27.

Claudiu, T. A. (2010). Forecasting credit groth rate in Romania: From crefit boom to credit crunch? Romanian Economic and Business Review, 5(1), 62-75.

Dennis, K., Muriithi, Ngeretha, A. N., Muriungi, R. G., \& Njoroge, E. W. (2014). Analysis of the fluctuation of gorss domestic product in Kenya using autoregressive integrated moving average model. Journal of Statistics: Advances in Theory and Applications, 11(1), 31-43.

Dinh, D. V. (2018). World crude iol impact on consumer price index. Advances and Applications in Statistics, 52(1), $33-54$.

Dinh, D. V. (2019). Analysed money supply and inflation: Evidence from Vietnam economy. Advances and Applications in Statistics, 56(2), 125-142.

Dinh, D. V. (2019). Applied individual investment risk measurement method to forecast expected return rate. International Journal of Applied Mathematics and Statistics ${ }^{\mathrm{TM}}$, 60-17.

Dinh, D. V. (2019). Money supply and inflation impact on economic growth. Journal of Financial Economic Policy, 11(3), $451-472$.

Emmanuel, K. M. (2016). Box-Jenkins modelling and forecasting of Brent crude oil price. MPRA Paper, 67748, 1-10.

Fapetu, O., \& Oblade, A. A. (2015). Sectoral allocation of banks' credit and economic growth in Nigeria. International Journal of Academic Research in Business and Social Sciences, 5(6), 161-169.

Fuat, S. (2011). Exchange rate volatility and stock returns for the U.S. African Journal of Business Management, 5(22), 96599664.

Glushan, K., Sanjeev, G. (2010). Forecasting exports of industrial good from Punjab-An application on univariate ARIMA model. Annals of the University of Petro şani, Economics, 10(4), 169-180.

Hodrick, R., \& Prescott, E. C. (1997). Postwar U.S. business cycles: An empirical investigation. Journal of Money, Credit, and Banking, 29(1), 1-16.

Ioana, M. B. (2013). The impact of credit on economic growth in the global crisis context. Procedia Economics and Finance, 6(6), 25-30. 
Jere, S., \& Mubita, S. (2016). Forecasting inflation rate of Zambia using Holt's exponential smoothing. Open Journal of Statistics, 6(2), 364-372.

Kishwer, S., Adila, R., Nighat, M., Sajida, A., \& Saghir, P. G. (2014). Forecasting inflation and economic growth of Pakistan by using two time series methods. International Journal of Business and Economics Research, 2(6), 174-178.

Mangasa, A. S., Rina, O., Hermanto, S., \& Bambang, J. (2016). Effects of credit on economic growth, unployment and poverty. Jurnal Ekonomi Pembangunan, 17(1), 37-49.

Maniha, Z. (2014). A time series modeling on GDP of Pakistan Journal of Contemporary Issues in Business Research, 3(4), 200-210.

Mehdi, K., \& Mehdi, B. (2011). A novel hybridization of artificial neural networks and ARIMA models for time series forecasting. Applied Soft Computing, 11(2), 2664-2675.

Mishkin, F. S. (2016). The Economics of Money, Banking, and Financial Markets. (11, Ed.) Columbia University: Pearson Education, Inc.

Muhammad, I. P., Amjad, N., \& Postdoc, f. (2016). Forecasting inflation: Autoregressive integrated moving average model. European Scientific Journal, 12(1), 83-92.

Muhammad, Z. I., Nisar, A. P., \& Zakir, H. P. (2012). Impact of savings and credit on economic growth in Pakistan. Pakistan Journal of Social Sciences, 32(1), 39-48.

Neelam, T. (2014). Impact of Bank Credit on Economic Growth in Nepal. NRB Working Paper, 22, 1-23.

Omekara, C., Okereke, O., \& E.Ehighibe, S. (2016). Time series analysis of Interest rate in Nigeria: A comparison of Arima and state space models. International Journal of Probability and Statistics, 5(2), 33-47.

Seher Nur, S. (2011). Testing the long-run neutrality of money in a developing country: Evidence from Turkey. Journal of Applied Economics and Business Research, 1(2), 65-74.

Sreerama, K., Sailaja, M., \& Wondaferahu, M. D. (2012). The long-runimpact of bank credit on economic growth in Ethiopia: Evidence from the Johansen's Multivariate cointegration approach. European Journal of Business and Management, 4(14), 20-33.

Suna, K. (2015). Impact of bank credits on economic growth and inflation. Journal of Applied Finance \& Banking, 5(1), 5769.

Tao, W. (2016). Forecast of economic growth by time series and scenario planning method. Modern Economy, 7(2), $212-222$.

Thabani, N. (2018). Modeling and Forecasting Naira / USD Exchange Rate In Nigeria: a Box - Jenkins ARIMA. MPRA Paper, 88622, 1-35.

Yakubu, N., \& Affoi, A.Y. (2014). An analysis of commercial banks' credit on economic growth in Nigeria. Current Research Journal of Economic Theory, 6(2), 11-15.

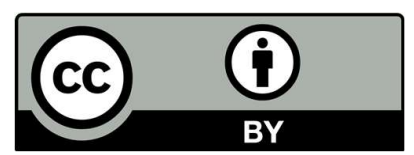

(C) 2020 by the authors; licensee Growing Science, Canada. This is an open access article distributed under the terms and conditions of the Creative Commons Attribution (CC-BY) license (http://creativecommons.org/licenses/by/4.0/). 